\title{
Identification of factors causing reproductive disorders of the cow found in North Labuhanbatu Regency, North Sumatera Province
}

\author{
Muharriza Nasution ${ }^{1}$, Tongku Nizwan Siregar ${ }^{2, *}$, Arman Sayuti ${ }^{3}$, Hafizuddin 2, Rosmaidar ${ }^{4}$, \\ Mulyadi Adam 5,* \\ ${ }^{1}$ Program Studi Pendidikan Dokter Hewan, Fakultas Kedokteran Hewan, Universitas Syiah Kuala, Banda Aceh, \\ 23111 \\ ${ }^{2}$ Laboratorium Reproduksi, Fakultas Kedokteran Hewan, Universitas Syiah Kuala, Banda Aceh, 23111 \\ ${ }^{3}$ Laboratorium Klinik, Fakultas Kedokteran Hewan, Universitas Syiah Kuala, Banda Aceh, 23111 \\ ${ }^{4}$ Laboratorium Farmakologi, Fakultas Kedokteran Hewan, Universitas Syiah Kuala, Banda Aceh, 23111 \\ ${ }^{5}$ Laboratorium Fisiologi, Fakultas Kedokteran Hewan, Universitas Syiah Kuala, Banda Aceh, 23111 \\ *Correspondence: siregar@unsyiah.ac.id; mulyadi_adam@unsyiah.ac.id; Telp.: +62-811-680-356
}

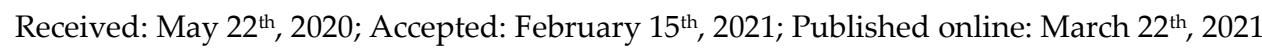

\section{Abstrak}

Tujuan: Identifikasi gangguan reproduksi pada sapi potong betina di Kabupaten Labuhanbatu Utara.

Metode: Ternak sapi yang mengalami gangguan reproduksi menjadi objek penelitian ini. Di samping itu, peternak yang sapinya mengalami gangguan reproduksi menjadi sumber data untuk kuesioner. Penelitian ini menggunakan metode survey dengan data primer dan data sekunder. Data primer diperoleh dengan cara membagikan kuesioner dan wawancara langsung ke peternak sedangkan data sekunder diperoleh dari laporan Upaya Khusus Sapi Indukan Wajib Bunting (UPSUS SIWAB) tahun 2017 di Kabupaten Labuhanbatu Utara. Data yang diperoleh terdiri atas identitas peternak, skor kondisi tubuh, jenis sapi, sapi yang mengalami gangguan reproduksi, manajemen pemeliharaan, catatan kunjungan dokter hewan/tenaga medis, hasil pemeriksaan kebuntingan, sinkronisasi birahi, pertolongan kelahiran, tipe perkawinan dengan 30 responden peternak dari 5 kecamatan. Data dianalisis menggunakan stepwise regression dengan bantuan SPSS.

Hasil: Dari 110 ekor sapi betina yang mengalami gangguan reproduksi, gangguan hipofungsi ovarium mencapai persentase tertinggi yakni 57,3\%. Korelasi paling kuat pada variabel independen terhadap variabel dependen adalah skor kondisi tubuh (sig. 0,043) dan pakan yang diberikan (sig. 0,046). Persamaan regresi yang diperoleh adalah $Y=-4,297+1,495 X_{1}+2,492 X_{2}$.

Kesimpulan: Faktor-faktor yang teridentifikasi memiliki korelasi terhadap gangguan reproduksi sapi betina adalah skor kondisi tubuh dan pakan.

Kata Kunci: UPSUS SIWAB; Gangguan reproduksi; Sapi potong betina; Labuhanbatu Utara 
Objective: This study aims to identify the factors that cause reproductive disorders in beef cattle in the North Labuhanbatu, North Sumatra.

Methods: The objects of this study were cattle with reproductive disorders and breeders whose cattle had reproductive disorders. This research used a survey method. Primary data was obtained by distributing questionnaires and conducting direct interviews with breeders, while secondary data was obtained by studying the 2017 report of UPSUS SIWAB (Indonesian Ministry of Agriculture's program to accelerate the fulfilment of domestic beef cattle population targets) in North Labuhanbatu Regency. The questionnaire covered the characteristics of cow with reproductive disorders including body condition score (BCS), type of cows, feed given to cows with reproductive disorders, maintenance management, veterinary/medical personnel visits, pregnancy checks, heat synchronization, birth assistance, type of mating, and the breeders identity. This questionnaire was distributed to 30 breeder respondents in 5 districts. Data were analyzed using stepwise regression with SPSS.

Results: The results showed that 110 cows had reproductive disorders, $57.3 \%$ of which experienced hypofunctional ovaries. The independent variable that has the strongest correlation to the dependent variable is the body condition score (sig. 0.043), followed by the feed given to the cows (sig. 0.046) with the regression equation $Y=-4.297+1.495 X_{1}+2.492 X_{2}$.

Conclusions: The identified factors that had correlation to reproductive disorders in female beef cattle are body condition score and feed.

Keywords: UPSUS SIWAB; Reproductive disorders; Beef cattle; North Labuhanbatu

\section{INTRODUCTION}

Along with the increasing population, demand for meat is increasing every year. To meet this demand, in 2016, Indonesian government through the Ministry of Agriculture launched the Special Efforts to Accelerate Pregnant Cattle and Buffalo Populations (UPSUS SIWAB) Number 48/Permentan/PK.210/10/2016 [1]. UPSUS SIWAB was launched to accelerate the increase in the population of pregnant cows and buffalo through integrated activities in a sustainable manner. The acceleration of population increase is carried out to meet the need for animal food products through Artificial Insemination (AI) or Intensification of Natural Mating (INKA) by implementing a reproductive management system [2]. The main objective of this reproductive management program is to obtain optimal production and maximum profits [3].

The productivity of beef cattle in Indonesia has not been able to meet the national demand [4]. According to Putro [5], the negative growth of the beef cattle population is a result of the imbalance between market demand and reproductive rate. The limitation of animal products (meat) is caused by the decrease in the calving rate of cows which causes a decrease in the livestock population in Indonesia [3]. Another factor that causes unproductive cows is reproductive disorders caused by disease and lack of feed [2].

The population of beef cattle in North Labuhanbatu Regency was 38,951 in 2014, 40,519 in 2015, and 41,924 in 2016 [6]. These show that the beef cattle population is experiencing slow growth. Facts in the field and the results of several scientific studies have proven that this condition is caused by a decrease in the reproductive performance of livestock due to reproductive disorders [3].

According to Toelihere [7], reproductive functional disorders are reproductive diseases that can be diagnosed through rectal exploration. The low animal health status and reproductive health are the main factor contributing to reproductive disorder [5]. Reproductive failure can be classified into three main factors: failure due to management factors (i.e. technical insemination, lack of food, mineral deficiency), internal factors, and other accidental factors (accidents and disorders). These accidental factors are 
generally found to be very sporadic, for example, dystocia, uterine torsion, etc. [8]. Generally, these three factors will cause fertility and pregnancy disorders in cows.

Some reproductive disorders that can cause fertility and pregnancy disorders are repeat breeding, inactive ovaries, hypofunctional ovaries, cystic ovaries, and endometritis [9]. Repeat breeding is influenced by many factors, including maintenance management $(31.70 \%)$, hormone deviation $(18.03 \%)$, and reproductive infection $(14.75 \%)$ [10]. A study in repeat breeders' report that all uterus $(100 \%)$ had a bacterial infection that causes sub-clinical endometritis which failed in fertilization or implantation [11].

Inactive ovaries refer to ovaries that do not perform an ovum-forming activity, which is characterized by a smooth ovary surface [12]. Meanwhile, hypofunction ovary refers to an ovary that has low activity in producing eggs or ova. Cattle that have hypofunctional ovaries generally experience silent heat, artificial heat (heat without ovulation), irregular heat cycles, and slow post-partum heat [13].

An ovarian cyst is a reproductive disorder in the ovaries that has the potential to cause breeding failure in livestock. Endometritis is a uterine disease caused by a bacterial infection. Cows with endometritis show symptoms of foul-smelling mucus that is leaking out of their vulva. Endometritis has the potential to cause infertility in livestock [14]. With the many factors that disrupt the reproductive process, this study aims to identify the factors that cause reproductive disorders in beef cattle in North Labuhanbatu Regency.

\section{MATERIALS AND METHODS}

This research was conducted in North Labuhanbatu, North Sumatra. All research activities were carried out from December 2018 to March 2019. This study used a survey method with primary data and secondary data. The primary data was obtained by distributing questionnaires and direct interviews with breeders as additional information, while the secondary data was obtained from the 2017 UPSUS SIWAB report in North Labuhanbatu Regency.

\section{Questionnaire preparation}

The questionnaire used included questions about the characteristics of cattle reproductive disorders such as repeat breeding, inactive ovaries, hypofunctional ovaries, cystic ovaries and endometritis, type of mating (natural/artificial insemination), types of cow, age of cows, body condition scores, cows with reproductive disorders (virgin/adult), feed (field grass/forage/ concentrate), maintenance management (free-range/confined), veterinarians/medical personnel visits history (non-existent/ incidental/continuous), pregnancy checks (present/absent), heat synchronization (present/absent), type of mating (AI/natural), and breeder's identity.

\section{Respondents}

The selection of respondents was carried out by purposive sampling regarding information from the UPSUS SIWAB data in North Labuhanbatu Regency. Of the 8 subdistricts in North Labuhanbatu Regency, five were selected: NA IX-X District, Marbau District, Aek Kuo District, Aek Natas District, and Kualuh Hulu District. The five districts were chosen because they had the largest population of cow. From each sub-district, two villages were sampled, and from each village, three farmers were sampled. The selection of the village sample and breeders used the same criteria as the selection of district samples, so the total sample used was 30 breeders.

\section{Data analysis}

The data obtained from this study analyzed using stepwise regression. Data were analyzed using stepwise regression with the help of SPSS.

\section{RESULT}

In this study, cattle in North Labuhanbatu are described through several characteristics such as cow's BCS, their feed, maintenance management, type of cow, veterinary visits, pregnancy checks, heat synchronization, birth assistance, type of 
mating, and age of cows as presented in the Table 1.

Cattle in the study generally had BCS with a score of $1(36.7 \%)$ and a score of 2 $(43.3 \%)$. The number of cows fed only grass tended to be higher, i.e. $63.3 \%$, while those given complete feed (grass + concentrate) was $36.7 \%$. In terms of maintenance management, $100 \%$ of the cattle were kept in pens; only in the morning, they were released into the pasture. Cows with reproductive disorders generally were Limousine type (53.3\%) and Bali cattle (46.6\%). The number of veterinarians/medical personnel who never visited farmers in North Labuhanbatu Regency was $46.7 \%$, veterinarians who made incidental visits were $40 \%$, and veterinarians who made regular visits were $4 \%$.

Table 1. Characteristics of cattle inspection in North Labuhanbatu Regency

\begin{tabular}{|c|c|}
\hline Factor & Total $(\%)$ \\
\hline \multicolumn{2}{|l|}{ Cow's BCS } \\
\hline Score 1 & $11(36.7)$ \\
\hline Score 2 & $13(43.3)$ \\
\hline Score 3 & $2(6.7)$ \\
\hline Score 4 & $4(13.3)$ \\
\hline \multicolumn{2}{|l|}{ Feed given to cows } \\
\hline Only grass & $19(63.3)$ \\
\hline Complete & $11(36.7)$ \\
\hline \multicolumn{2}{|l|}{ Maintenance management } \\
\hline Intensified & $30(100)$ \\
\hline Free-range & $0(0)$ \\
\hline \multicolumn{2}{|l|}{ Type of cows } \\
\hline Limousin & $16(53.3)$ \\
\hline Bali & $14(46.6)$ \\
\hline \multicolumn{2}{|c|}{ Veterinarian/medical personnel visit } \\
\hline None & $14(46.7)$ \\
\hline Incidental & $12(40.0)$ \\
\hline Continuous & $4(13.3)$ \\
\hline \multicolumn{2}{|l|}{ Pregnancy examination } \\
\hline Yes & $19(63.3)$ \\
\hline No & $11(36.7)$ \\
\hline \multicolumn{2}{|l|}{ Heat synchronization } \\
\hline Yes & $26(86.7)$ \\
\hline No & $4(13.3)$ \\
\hline \multicolumn{2}{|l|}{ Birth assistance } \\
\hline Yes & $24(80.0)$ \\
\hline No & $6(20.0)$ \\
\hline \multicolumn{2}{|l|}{ Type of Mating } \\
\hline Natural & $18(60.0)$ \\
\hline AI & $12(40.0)$ \\
\hline \multicolumn{2}{|l|}{ Age of cow } \\
\hline Virgin & $16(14.5)$ \\
\hline Adult & $94(85.5)$ \\
\hline \multicolumn{2}{|c|}{ Reproductive disorder often found } \\
\hline Repeat breeding & $19(17.3)$ \\
\hline Inactive ovaries & $12(10.9)$ \\
\hline Hypofunctional ovaries & $63(57.3)$ \\
\hline Endometritis & $5(4.5)$ \\
\hline Persistent corpus luteum & $11(10.0)$ \\
\hline Cystic ovaries & $0(0)$ \\
\hline
\end{tabular}


Cows in the study were generally not given pregnancy examinations (63.3\%), only $36.7 \%$ received pregnancy examinations. Most of the breeders (86.7\%) tended not to do heat synchronization to their cows; only $13.3 \%$ did. Most cows $(80.0 \%)$ did not receive birth assistance; only $20.0 \%$ did. Most of the cows mated naturally $(60.0 \%)$, while the remaining $40.0 \%$ were given AI. Among the adult cattle, $85.5 \%$ had reproductive problems, and among the heifers, $14.5 \%$ had reproductive problems.

Of the 110 cows with reproductive problems, $57.3 \%$ had ovarian hypofunction, $17.3 \%$ experienced repeat breeding; $10.9 \%$ had inactive ovaries, $10.0 \%$ had persistent corpus luteum, $4.5 \%$ had endometritis and none had cystic ovaries. The factors that cause reproductive disorders in cattle in North Labuhanbatu Regency are presented in Table 2.

In the stepwise regression test, the dependent variable was reproductive disorders in cows North Labuhanbatu Regency and the independent variables include cow's BCS, feed given to the cows, maintenance management, veterinary/ medical personnel visit, pregnancy checks, heat synchronization, birth assistance, type of cow, age of cows and type of mating. From the results of this test, it is known that the independent variable with the strongest correlation is BCS (sig. 0.043), followed by cow feed (sig. 0.046). Both of these factors have the strongest correlation so they have a significant effect on reproductive disorders in cattle in North Labuhanbatu Regency. The regression equation obtained is $\mathrm{Y}=-4,297+1,495 \mathrm{X} 1+2,492 \mathrm{X} 2$, with $\mathrm{Y}$ referring to the incidence of reproductive disorders, X1 referring to the BCS of the cows, and $\mathrm{X} 2$ referring to the type of feed given to the cows.

\section{DISCUSSION}

Of the 110 cows with reproductive disorders, $57.3 \%$ had hypofunctional ovaries; $17.3 \%$ repeat breeders, $10.9 \%$ inactive ovaries; $10.0 \%$ had a persistent corpus luteum; $4.5 \%$ had endometritis and no cattle had cystic ovary. Hypofunction ovary has a low activity to produce eggs or ova [9]. Reproductive disorders that occur in cattle with hypofunctional ovaries indicate an error in the reproductive hormone mechanism. Mechanical errors can be due to nutritional imbalance [20] and poor BCS [19].

BCS is used to evaluate feed management, assess the health status of individual livestock, and improve livestock conditions during routine livestock management [15]. The results of this study are following the statement of Budiawan et al. [16] that BCS has a relationship with livestock reproduction; if livestock has bodyweight that exceeds the ideal body weight, they will experience reproductive disorders and metabolic diseases, and conversely, less than ideal body weight will have an impact on the livestock reproductive system. Very thin cattle have low-fat reserves, so their reproductive rate is also low. Bearden and Fuquay [17] stated that obesity in cows can lead to the accumulation of fat in the reproductive tract, especially the ovaries, which can cause sexual disruption of the heat cycle. Other consequences that can arise from obesity are low pregnancy rates, dystocia, abortion, and retentio secundinae.

The BCS value below 2.0 as in the results of this study illustrates the condition of the bodyweight of cows that are severely malnourished so that the bodyweight is not ideal to support the function of the reproductive system. In this group, it was determined that the reproductive system could be normalized again after BCS

Table 2. Factors that cause reproductive disorders in North Labuhanbatu Regency

\begin{tabular}{lcc}
\hline \multicolumn{1}{c}{ Factors that cause reproductive disorders } & Sig. & B \\
\hline BCS & 0.043 & 1.495 \\
The feed & 0.046 & 2.429 \\
Constant & 0.029 & -4.297 \\
\hline
\end{tabular}

Notes: Sig. $<0.05$ indicates a significant effect, B indicates the value of the regression coefficient (value of increase or decrease) 
is increased to 2.0 [18].

The second factor that has high correlation to reproductive disorder is the feed (the nutrients obtained). Poor management of cattle rearing in terms of feeding can be the cause of reproductive disorders [9]. The results showed that the breeders in North Labuhanbatu Regency generally only provided grass without additional concentrate to the cattle. The feed provided by farmers was only field grass or straw, which is also a factor in causing reproductive disorders [19]. This is consistent with the statement of Pradhan and Nakagoshi [20], that the reproductive fertility of livestock is influenced by the nutrition obtained by livestock and plays an important role in the reproductive cycle. Lack of nutritional intake adversely affects both the production and reproduction of the livestock. Nuryadi and Wahjuningsih [21] added that balanced nutrition is very important for the continuity of cattle reproduction. Usually, if feed nutrition is deficient in livestock, the livestock will naturally experience disturbances in production and reproduction. According to Winugroho [22], nutritional deficiencies such as the lack of protein, energy, minerals, and vitamins will cause late estrus, silent heat, or anestrus. Lack of protein causes weak sexual desire, calm desire, anestrus, and repeat breeding. Besides, nutrition and mineral deficiency and imbalance also affect repeat breeding, ovarian activity, and low reproductive efficiency.

Repeat breeding is the second highest reproductive disorder with overall prevalence is $17.3 \%$. Repeat breeding is likely influenced by many factors, including maintenance management $(31.70 \%)$, hormone deviation $(18.03 \%)$, and reproductive infection (14.75\%) [23]. To reduce repeat breeding, it is necessary to improve the feed quality of pregnant cows and post-partum cows to accelerate the onset of post-partum heat and improve the egg quality of cow, thus they can produce a calf every year [23]. The good feed has complete and balanced nutrition including vitamins and minerals [20].

Inactive ovaries are the third highest reproductive disorder with the prevalence is $10.7 \%$. Inactive ovaries do not perform an ovum-forming activity, which is characterized by a smooth ovary surface [24]. Extreme factors that cause ovarian inactivity include stress and severe nutritional deficiencies $[12,24]$. This study revealed that low nutritional quality of the feed given to cows by the breeders, as reflected in the type of feed given and the number of cows with BCS, did not allow the reproduction process to occur properly.

\section{CONCLUSION}

The identified factors that had correlation to reproductive disorders in female beef cattle are body condition score and feed.

\section{CONFLICT OF INTEREST}

The authors state that there are no financial, personal, or other conflicts of interest with other people or organizations regarding the material discussed in the manuscript.

\section{REFERENCES}

1. Kementan. 2016. Upaya Khusus Percepatan Peningkatan Populasi Sapi dan Kerbau Bunting. Permentan. No 48/ Permentan/PK.210/10/2016. Jakarta, ID.

2. Inounu, I. 2017. Dukungan sains dan teknologi reproduksi untuk mensukseskan program sapi indukan wajib bunting. Wartazoa. 27(1):23-34. Doi: 10.14334/ wartazoa.v27i1.1368

3. Gitonga, P.N. 2010. Postpartum reproductive performance of dairy cows in medium and large scale farms in kiambu and nakuru districts of Kenya. Doctoral Dissertation, University of Nairobi. Nairobi, KE.

4. Rusdiana, S., and L. Praharani. 2018. Development of people's people livestock: SWAT private vocational policy and feasibility of animal businesses. Forum Penelitian Agro Ekonomi. 36(2): 97-116. Doi: 10.21082/fae.v36n2.2018.97-116

5. Ariningsih, E. 2014. Performance of national beef self-sufficiency policy. Forum Penelitian Agro Ekonomi, 32(2):137-156.

6. Utara, B. P. S. K. L. 2016. Populasi Ternak Menurut Kecamatan dan Jenis Ternak di 
Kabupaten Labuhanbatu Utara 2016. Labuhanbatu Utara, ID.

7. Luthfi, M., and Y. Widyaningrum. 2017. Tingkat kejadian gangguan reproduksi sapi bali dan madura pada sistem pemeliharaan kandang kelompok. Pros. Semnas TPV. p. 101-108. Doi: 10.14334/Pros.Semnas.TPV-2017

8. Partodiharjo, S. 1987. Ilmu Reproduksi Hewan. Mutiara Sumber Widya, Jakarta, ID.

9. Sutiyono, D. S., and A. Suryawijaya. 2017. Identifikasi gangguan reproduksi sapi betina di peternakan rakyat. J. Vet. 18(4): 580-588. Doi: 10.19087/jveteriner.2017.18. 4.580

10. Singh, J., D. Dadarwal, M. Honparkhe, and A. Kumar. 2009. Incidences of various etiological factors responsible for repeat breeding syndrome in cattle and buffaloes. Internet J. Vet. Med. 6(1): 1-6.

11. Ahmed, F. O., and A. S. Elsheikh. 2014. Treatment of repeat breeding in dairy cows with Lugol's Iodine. IOSR J. Agric. Vet. Sci. 7(4): 22-26. Doi:

12. Britt, J. H. 2008. Oocyte development in cattle: physiological and genetic aspects. Rev. Bras. Zootech. 37:110-115. Doi: 10.1590/S1516-35982008001300013.

13. Luo, R., and X. Gu. 2009. Treating infertile milk cows by traditional Chinese medicine. J. Agricult. Sci. 1(1):82-85. Doi: 10.5539/ jas.v1n1p82

14. Williams, E. J., D. P. Fischer, D. U. Pfeiffer, G. C. England, D. E. Noakes, H. Dobson, and I. M. Sheldon. 2005. Clinical evaluation of postpartum vaginal mucus reflects uterine bacterial infection and the immune response in cattle. Theriogenology. 63(1): 102-117. Doi: 10.1016/j.theriogenology.2004 .03 .017

15. Susilorini, T. E., and M. E. Sawitri. 2008.
Budidaya 22 ternak potensial. Penebar Swadaya Grup, Jakarta, ID.

16. Budiawan, A., M. N. Ihsan, and S. Wahjuningsih. 2015. Hubungan body condition score terhadap service per conception dan calving interval sapi potong Peranakan Ongole di Kecamatan Babat Kabupaten Lamongan. J. Trop. Anim. Product. 16(1):34-40.

17. Bearden, H. J., and J. W. Fuquay. 1984. Applied Animal Reproduction. Reston Publishing Company Inc., Virginia, US.

18. Direktorat Jenderal Peternakan dan Kesehatan Hewan. 2016. Pedoman Teknis Gangguan Reproduksi. Jakarta, ID.

19. Eversole, D. E., M. F. Browne, J. B. Hall, R. E. Dietz. 2009. Body condition scoring beef cows. Life Sciences, Virginia Polytechnic Institute and State University, US.

20. Pradhan, R., and N. Nakagoshi. 2008. Reproductive disorders in cattle due to nutritional status. J. Int. Developm. Cooperation. 14(1):45-66.

21. Nuryadi, N., and S. Wahjuningsih. 2012. Penampilan reproduksi sapi peranakan Ongole dan peranakan Limousin di Kabupaten Malang. J. Trop. Anim. Product. 12(1):76-81.

22. Winugroho, M. 2002. Strategi pemberian pakan tambahan untuk memperbaiki efisiensi reproduksi induk sapi. J. Lit. Bang. Perta. 21(1):19-23.

23. Bindari, Y. R., S. Shrestha, N. Shrestha, and T. N. Gaire. 2013. Effects of nutrition on reproduction-A review. Adv. Appl. Sci. Res. 4(1):421-429.

24. Gupta, D. 2015. Study on sterile and substerile conditions in cow and buffalo in Mawana tehsil of District Meerut Uttar Pradesh. Res. J. Anim. Husb. Dairy Sci. 6(1):83-84. Doi: 10.15740/ HAS/RJAHDS/6.1/83-84. 